\title{
Zigmunde, Alīda. Die Entwicklung der Gehörlosenbildung in Lettland von den Anfängen in Livland und in Kurland bis zur Gegenwart, Riga: RTU Verlag, 2011, 157pp. ISBN 978-9934-10-241-7.
}

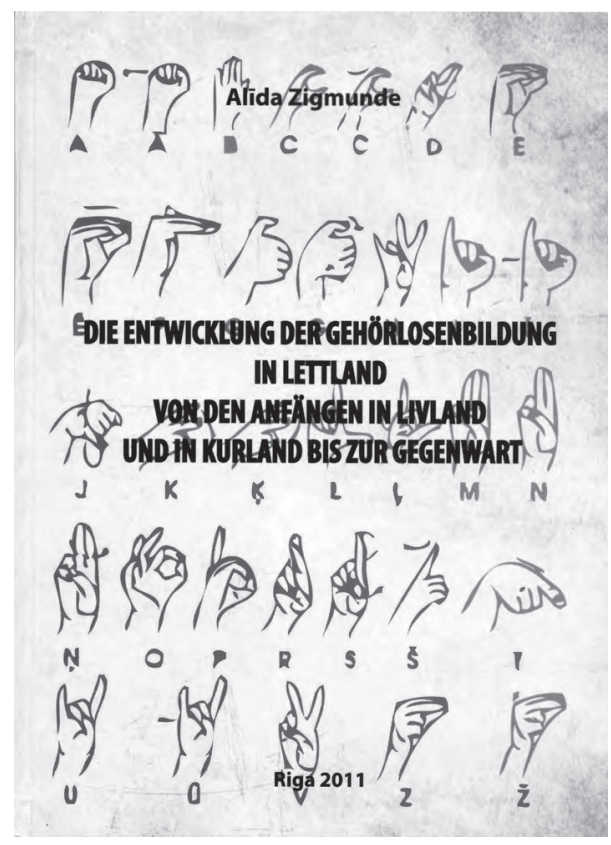

It is not difficult to make a survey of the early history of the education of the deaf in Europe. A book on this subject, readily available on the Internet, is titled The Earliest History of Deaf Education in Europe and it was written by Henk Betten from the Netherlands, who was born deaf. In this book, published in English, the subject matter is explored from the perspective of 38 European countries in alphabetical order, from Albania to Wales. One of the countries studied is Latvia. The book also mentions that the year 2010 marks the $250^{\text {th }}$ anniversary of the beginning of education of the deaf.

The anniversary celebrates the foundation of the first institution for the education of the deaf, which was established by Abbé Charles-Michel de l'Épée in Paris in 1760. Education of the deaf in the Baltic provinces was started in the $18^{\text {th }}$ century in Pernau (or Pärnu, on the current territory of Estonia) by Jakob Wilde (16791755). Wilde was born in Bauskè/Bauska, a former province of Courland, and was a student at the Riga cathedral school (Domschule). He was the vice rector of this school from 1701 to 1703 . From 1705 to 1709, Professor Wilde lectured at the University of Dorpat and at the same time provided education for the deaf in Pernau. After leaving Pernau, he left the task of educating the deaf to Heinrich Niederhoff, the head pastor of the St Nicholas' Church in Pernau and school inspector. Pastor Niederhoff died in 1709 and it is unknown what happened to the education of the deaf from then on. These are the facts given in the above-mentioned publication by Henk Betten. Another book on this subject was published in 1903 in Reval/ Tallinn by the teacher and theologian August Constantin Hörschelmann. In his 
Übersicht über das Werk der Taubstummenbildung der Anstalten Russlands ('Survey of the institutions for the education of the deaf in Russia'), Hörschelmann briefly describes the situation in the Russian Provinces of Livonia and Estonia. Betten made extensive use of this book and also received additional information from corresponding with some Estonian teachers. A short survey of the situation in Latvia is also included in Betten's book.

A more detailed description of the education of the deaf in Latvia, however, is available in the book entitled Die Entwicklung der Gehörlosenbildung in Lettland von den Anfängen in Livland und in Kurland bis zur Gegenwart by the Latvian researcher Dr. Alida Zigmunde from the Riga Technical University. The book, written in German, was published in Riga in 2011 and is dedicated to the bicentennial of the education of the deaf and respective institutions in Riga. The first schools for the deaf in Livonia were the school founded in 1809 by Carl August Jakobi and the institution for the deaf founded in 1832 by Dr. Ph. Bornhaupt and Daniel Heinrich Senß. In Riga, the then capital of Livonia, the Literärisch-praktische Bürgerverbindung, the public association for literary and practical purposes, assumed the responsibility for the foundation and activities of the institution for the deaf (1839-1918). In this context it is important to emphasize the contribution of Jacob Gottfried Stünzi from Switzerland and his followers to the education of the deaf in the Baltic region. In Courland, schools for the deaf were established in Kirchholm, Carolinenhof and Mitau, the capital of Courland (1870-1915). A separate chapter of Zigmunde's book is dedicated to the school for the deaf of Livonia in Wolmar (1875-1915).

The book does not only provide the reader with historical facts, the names of teachers, and of schools, but also a description of international contacts and their influence on the education of the deaf in Livonia and Courland.

The education of the deaf in Livonia, which is divided between the presentday states of Latvia and Estonia, shares a common history and bears obvious resemblances. In 1866, Johannes Eglon, who was educated at the Jānis Cimze's Teachers' Seminary in Valka, present-day Latvia, opened a school there. Together with Philipp Schwede, his schoolmate at the Cimze's seminary, and Stünzi, the headmaster of the school for the deaf in Riga, Eglon later visited the most outstanding institutions for the education of the deaf in Germany and Switzerland. Archive reports reveal that Stünzi later visited the school for the deaf-mutes in Vändra, Estonia. Later teachers of the schools for the deaf cooperated with their colleagues in other schools for the deaf and profited from these experiences. 
As to the first period of independence in Latvia (1918-1940), there were reports of the activities of the school for the deaf in Riga (1918-1940), the state schools for the deaf in Mitau and Wolmar (1920-1940) and the youngest state school for the deaf in Laizāni, Latgale region (1923-1940). The history of Verein der Lehrer der defektiven Kinder Lettlands ('Association of the teachers of "defective" children in Latvia') and other associations for the deaf, their foundation and activities, are described in further detail.

A chapter in Zigmunde's book is dedicated to the education of the deaf in the Soviet times (1940-1990) and during the Second World War (1941-1944). The chapter discusses the situation of the school for the deaf in the capital Riga (1941-1962), the state school for the deaf in Riga (1941-1962), the boarding school for deaf children in Riga (1962-1990), the state school for the deaf in Mitau (1940-1960), the state school for the deaf in Laizāni (1940-1956), the elementary school for the deaf in Rēzekne (1957-1990) and the state school for the deaf in Wolmar (1940-1958).

The final chapter analyzes the current situation in the education of the deaf and the hearing-impaired schoolchildren.

The annex includes institutional regulations concerning the education of the deaf in respective institutions in Livonia and Courland (1873), the program of the institution in Riga (1899), instructions for the governing board (Kuratorium) from 1874, instructions for the teaching personnel of the institution in Riga from 1901, the daily schedule of the institution in Riga (1901), and the requirements and regulations for the acceptance of students in Fennern (1892).

The volume with its 157 pages, many photos and an extensive index of persons mentioned in the text is an interesting book not only for experts, but also for the non-professional audience. It is available in major libraries in the Baltic States, Germany, Switzerland, and in the Library of Congress of the United States.

\section{Eckhard Spring}

Thüringer Str 57,

Darmstadt 64297, Germany

E-mail: EckhardSpring@t-online.de 